\title{
'Give'-type verbs and basic alignments: a comparison between Sikuani and Katukina-Kanamari
}

\author{
Verbos de tipo 'dar' e alinhamentos básicos: uma comparação entre Sikuani e \\ Katukina-Kanamari \\ Francesc QUEIXALÓS* \\ Centre National de la Recherche Scientifique \\ Institut de Recherche pour le Développement
}

\begin{abstract}
Why verbs expressing events that necessarily involve three participants are not found as formally three-place verbs in languages of the so-called syntactically-ergative type? Although the fact is acknowledged in the literature, no thorough account for such state of affairs appears to be available. A comparison between two unrelated languages, one homogeneously accusative, the other homogeneously ergative, is put to the purpose of supplying some clues to the rationale behind this observed incompatibility.
\end{abstract}

KEY-WORDS: Argument structure. Alignment. Trivalent verbs.

RESUMO: Por que os verbos que expressam eventos em que três participantes estão necessariamente envolvidos não ocorrem como verbos "ditransitivos" em línguas do tipo chamado de sintaticamente ergativo? Embora o fato seja reconhecido na literatura, não parece haver uma justificativa explícita para tal estado de coisas. A comparação de duas línguas sem parentesco genético, uma uniformemente acusativa, a outra uniformemente ergativa, fornece alguns indícios sobre o que seria a explicação por trás dessa observação empírica.

PALAVRAS-CHAVE: Estrutura argumental. Alinhamento. Verbos trivalentes.

\footnotetext{
* Doutor em Linguistica Geral - Universidade de Paris IV (Paris-Sorbonne) (1980) e doutorado ("d'Etat") em Letras e Ciências Humanas - Universidade de Paris IV (Paris-Sorbonne) (1995). Atualmente é pesquisador no Centre National de la Recherche Scientifique e no Institut de Recherche pour le Développement (França). E-mail: qxls@vjf.cnrs.fr
} 


\section{Introduction}

Cross-linguistically the cohabitation, within one and the same language, of underived three-place verbs of the 'give' type and the argument alignment known as syntactically ergative seems to be banned. In this paper I am at tracing an explanation of this observational fact by interpreting data from two typologically contrasted languages. The first section provides a brief typological synopsis of the main types of argument structure found for the equivalents of 'give' across languages. The second section overviews the basic grammatical characteristics of Sikuani and Katukina-Kanamari. The third section deals with the properties of formally trivalent 'give'-clauses in the accusative language Sikuani, and those of formally divalent 'give'-clauses in the ergative language Katukina-Kanamari. Section fourth proposes a clue to the understanding of the difference between both languages, rooted in the basic alignment of arguments in monoand di-valent clauses. ${ }^{1}$

\section{Argument structure of 'give' verbs}

Although any linguistic community has, conceivably, to deal with threeparticipant events of the type 'give', 'say', 'lend' and so on, not all languages have nonderived three-place verbs when it comes to the number of syntactic arguments upon which a given predicate projects its semantic participants. Let us call these participants agent / patient / recipient, corresponding, in a more fine-grained semantic characterization, to source / transferee / destination respectively. The basic linguistic expression of such a state of affairs has the agent realized as argument. The other two participants compete mutually in accessing argumenthood status. Languages exhibit rather diverse ways as to settle such a competition. (In what follows I will use superscripts ${ }^{\mathrm{I}} / \mathrm{II}$ to flag the valency of a given verb, for instance $\mathrm{I}^{\mathrm{v}}$ erb $v$ s. ${ }^{\mathrm{II}}$ verb.)

\footnotetext{
${ }^{1}$ As an attempt at terminological prophylaxy, I use argument for a linguistic expression — including zero — that bears a structural relationship to a predicate ( $c f$. "syntactic argument"), along with representing one of the semantically obligatory participants ( $c f$. "core participant"). Arguments qualify as nominative, accusative, etc.; participants as agent, patient, etc.; and grammatical relations as subject, object, etc. Additionally, all types of meanings conveyed by predicates - actions, events, processes, states, properties, qualities, inclusion, identification, comparison, possession, etc. — will be here subsumed under the cover phrase manner-of-existing. Finally, an adjunct is an expression bearing no direct syntactic relation to the predicate and denoting either a participant or a (secundary) manner-of-existing.
} 
Some languages are ${ }^{\mathrm{III}}$ verb-less: among non-agent participants they only allow one as core, the other being ascribed to the adjunct area. Tiriyo (Meira 1999 512) retains the patient as core, while Huichol (Comrie 1981 63) and Lummi (Jelinek 1990) do things the other way around: they select the recipient as core. Now, combining both options in a single language may result in a lexical split as in Yup'ik (Mithun 2000). !Xun (König \& Heine 2011) takes a step forward in the same direction: a single verb 'give' has alternatively — and in all formal respects - eiher the patient or the recipent as argument, the other participant being treated as an adjunct. One phonological shape, one descriptive meaning, two fluidly interrelated argument-structures. A language that allows patient and recipient be both projected as arguments, i.e. a ${ }^{\text {III }}$ verb-language, is likely to display what I propose to dub object zone: the morphosyntactic arena within which such a competition, now between arguments, takes place. In the object zone, asymmetries based in coding and behaviour properties will hierarchize the arguments on account of the latter's differential alignement with the single non-agent argument of II verbs. In this respect, French is patient-prominent, and Chi-mwi:ni (Kisseberth \& Abasheikh 1977) is recipient-prominent. Japhug (Jacques 2021 579) splits the class of ${ }_{\text {III }}$ verbs into patient-prominent and recipient-prominent. Somewhat parallely to II verblanguages patterning like !Xun, some ${ }^{\text {III }}$ verb-languages feature a fluid hierarchy in the object zone, that is, they ascribe to the same verb two alternative basic constructions mutually inverting the hierarchy. Purepecha is a (partial) instance of that (Chamoreau 2008; see below for some qualification).

A further distinction obtains between ${ }^{\text {III }}$ verb-languages that allow for renegociating the formal hierarchy by means of some syntactic derivational device (alternation), and those which do not. Among the patient-prominent languages, English ${ }^{2}$ features the so-called dative-shift, which promotes the recipient, while French does not. Among the recipient-prominent languages, Sikuani has what Dryer calls antidative, which promotes the patient, while Ojibwa (Dryer 1986) does not.

Finally, a few ${ }^{\text {III }}$ verb-languages do not seem to give raise to any asymmetry in the object zone. Ainu (Bugaeva 2011), Yagua (Payne and Payne 1990) and Matses (Fleck 2003) belong to this class: no competition, no hierarchy. Morphosyntactically

${ }^{2}$ A III verb-language to the extent that the to-phrase can be assigned the indirect object status ( $c f$. Andrews 2007 for some discussion). 
both arguments are placed on an equal footing not only as to coding but also regarding accessibility properties (Keenan \& Comrie 1977).

Table 1.

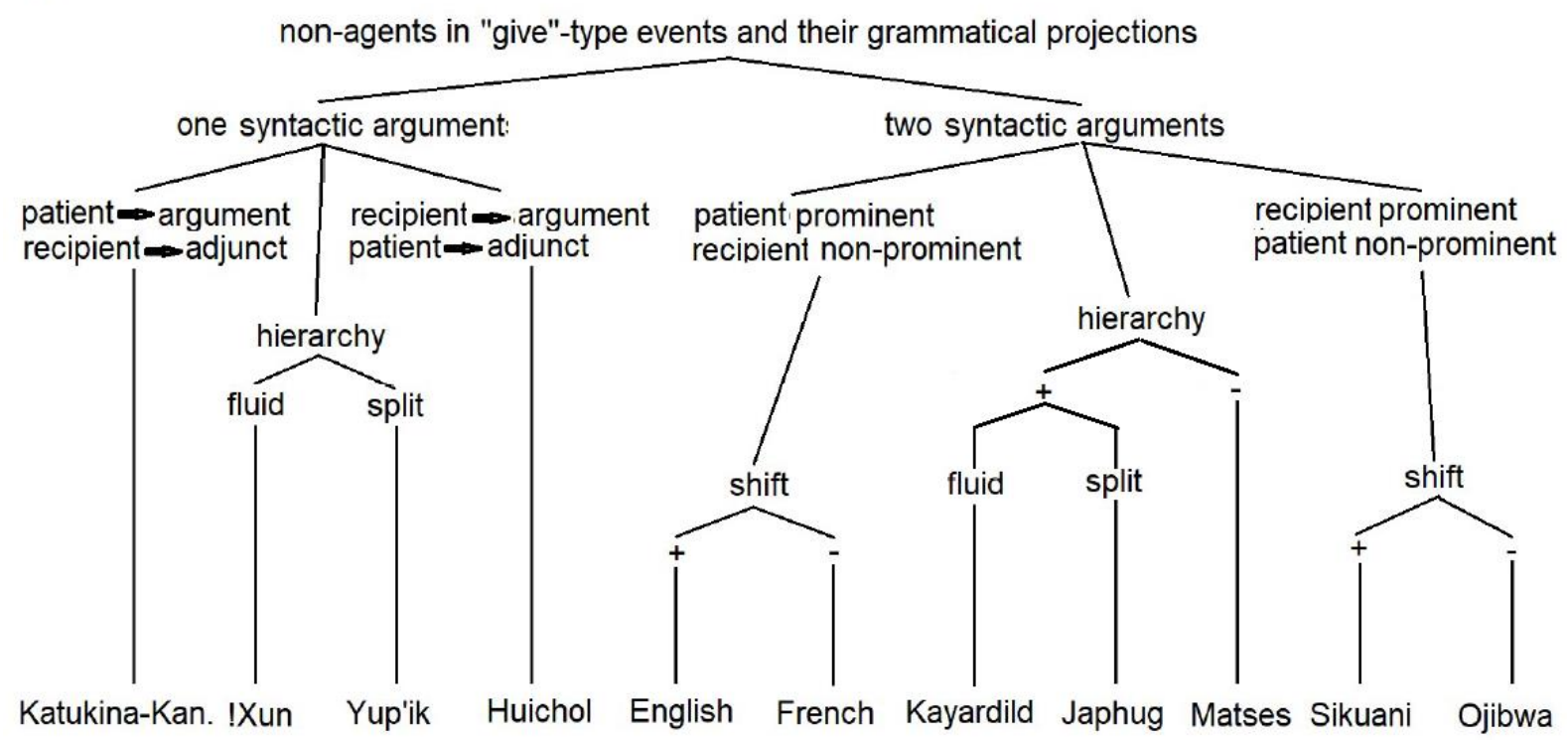

Haspelmath (2005) and Malchukov et al. (2011) provide a number of more nuanced distinctions.

\section{Typological outlines}

When viewed in concert, the contrasting grammatical make-ups of Sikuani and Katukina-Kanamari sugggest themselves as an opportunity to test how far-reaching the basic argument-alignments can be for a number of important typological issues such as the semantic structure of verbs, valency and valency-changing devices, voice, dependency marking, constituency and word-order, grammatical relations, and so on. We will attend to several of these below.

\subsection{Sikuani}

A member of the Guahiban family, Sikuani is spoken in the mid-course of the Orinoco river, principally in the savanna area of Eastern Colombia. The data come from the low Vichada, a left tributary of the Orinoco. The language is agglutinative regarding morphology, and predominantly suffixal. Word classes sub-divide into nouns, verbs, 
adjectives, adverbs, pronouns and particles. Adjectives — a small inventory — are not properly free standing words: in attributive position they are right-bound to their nominal head, and as predicates they need to be nominalized. Nouns do not need a copula to occur as predicates. Dependency is clearly head-marking. Constituency does not feature strong constraints. However, phrases encompassing more than one lexical element are clearly right-headed.

According to their primary lexical valency, verbs belong to three classes, one-, two-, and three-place verbs. See the first two in:

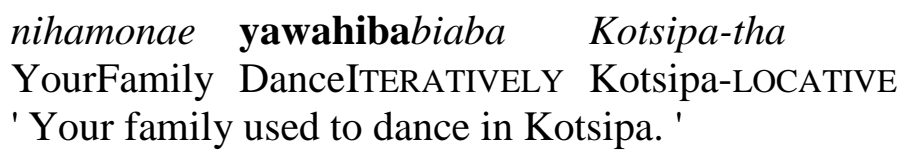

$$
\begin{aligned}
& \text { nihamonae penahorobinü itoya } \\
& \text { YourFamily shaman hate } \\
& \text { 'Your family hates the shaman. ' }
\end{aligned}
$$

No case morphology appears on noun phrases expressing arguments. Adjuncts are obliquely marqued (cases or non-inflectable postpositions), as Kotsipa in (1). Adpositional verbs (two arguments, one of them obliquely marked) do not exist. In terms of higher frequency and lesser pragmatic / situational conditions, the basic position of noun phrases relative to verb is as in the examples above, that is: unique argument $+{ }^{I}$ verb, and agent argument + patient argument $+{ }^{{ }^{I I}}$ verb, respectively. In spontaneous speech, noun phrases are frequently elided and, when overt, able to move to other positions within the limits - somewhat hazy - of non-ambiguity between semantic roles. Arguments are indexed on the verb by prefixed and suffixed person series, distinguishing:
(3) first
second
ne- $\quad-h \ddot{u}$
$k a-\quad$ verb $\quad-m e$
$\varnothing-$
third
first inclusive
aka- $\quad-t s i$

Alignment between monovalent and divalent clauses in terms coding can only be observed on verbal morphology since noun phrasess bear no case marking, and in the divalent clause both noun phrases are located on the same side of the ${ }^{\mathrm{II}}$ verb, (1). The alignment is accusative: the suffixed series stands for the unique argument of ${ }^{\mathrm{I}}$ verbs and 
the agent argument of ${ }^{\mathrm{II}}$ verbs, the prefixed series stands for the patient argument of II verbs.

(4) ponapona-me Kotsipa-tha

live-2NOMINATIVE Kotsipa-LOCATIVE

'You live in Kotsipa. '

(5) penahorobinü̈ $\emptyset_{1}$-itoya-me $\mathbf{m}_{2}$

shaman 3ACCUSATIVE-hate-

2NOMINATIVE

' $\mathrm{You}_{2}$ hate the $\operatorname{shaman}_{1}$.'

(6) penahorobinü $\mathbf{k}_{1} \mathbf{k a}_{2}$-itoya- $\emptyset_{1}$

shaman 2ACCUSATIVE-hate-3NOMINATIVE

' The $\operatorname{shaman}_{1}$ hates you 2. '

Arguments also align accusatively as to behaviour properties. Only noun phrases coindexed with a nominative suffix can be placed under the scope of a particle baitsi used for emphasizing the introduction of a new participant, (7)-(8). Nominative control of coreference occurs with high text-frequency on coordinated clauses. As for subordination, various types of dependent clauses also favor nominative pivots.

(7) nakua $_{1}$ baitsi nahumetsiana- $\varnothing_{1}$

world OVERTHEMATIZER ${ }^{3}$ WillRumble-3NOMINATIVE

' As for the world, it will rumble. '

(8) newüth ̈̈ 1 baitsi $\quad$ tsala $_{2} \quad \emptyset_{2}$-xane- $\emptyset_{1}$ jaguar OVERTHEMATIZER porcupine 3ACCUSATIVE-eat-3NOMINATIVE ' The jaguar ${ }_{1}, \mathrm{it}_{1}$ ate the porcupine ${ }_{2}$.'

Sikuani is, regarding coding and behaviour, a typically accusative language:

\begin{tabular}{l|l|l}
$\begin{array}{l}\text { semantic roles } \\
\text { argument coding } \\
\text { grammatical relations }\end{array}$ & $\begin{array}{l}\text { agent } \\
\text { nominative } \\
\text { subject }\end{array}$ \\
Everb argument & $\begin{array}{l}\text { patient } \\
\text { accusative } \\
\text { object }\end{array}$
\end{tabular}

Voice is an agent's demotion device which 1. only occurs with all third-person participants; 2 . blocks the access of any referent to the nominative position of ${ }^{\mathrm{II}} \mathrm{verbs}$ by saturating it with the nominative suffix for first person plural inclusive, -tsi, that in this

${ }^{3}$ Theme is here taken in the Praguian sense. Cf. Givón's notion of topic (2001 191). 
context occurs as void of any reference (I will hereafter gloss it as fourth person, owing to its special grammatical properties); 3. does not promote patient to nominative, since the only pronominal index retained for reference is the accusative, (10). At the syntactic level, notwithstanding, the occurrence of the fourth person promotes the accusative to subject status by allowing it access over-thematization, compare : (11)-(7)-(8). We have thus a "split" passive, non-promotional in morphology, but promotional in syntax.

(10) penahorobinü̈ $\emptyset_{1}$-itoya-tsi $\mathbf{i}_{0}$ shaman 3ACCUSATIVE-hate-4NOMINATIVE

' The shaman is hated. '
(11) penahorobinü $\ddot{1}_{1}$
baitsi
$\emptyset_{1}$-itoya-tsi $i_{0}$ shaman OVERTHEMATIZER 3ACCUSATIVE-hate-4NOMINATIVE
'As for the shaman, he is hated.'

Of course, the availability of speech-act participants involved in the contextsituation where (10) occurs allows for some amount of ambiguity with ' You and me (and others), we hate the shaman. ' The same cannot be true of (11) since the noun phrase preceding baitsi must be a nominative.

\subsection{Katukina-Kanamari}

Katukina-Kanamari belongs to the small Katukinan family of Central-Western Amazonia, perhaps the sole extant language of the family, and is spoken between the Purus and the Javari rivers, two Southern tributaries of the middle Amazon. Differences between Katukina from Bia and Kanamari are unmistakably dialectal. Morphology is rather parsimonious. Word-classes include nouns, verbs, adverbs, pronouns and particles. No class of adjectives exists. Strong constituency appears as a pivotal feature of the language's grammatical make-up. Complex phrases are right-headed. Non-verbal predicates occur without a copula, excepted for a facultative existential copula.

The language distinguishes between monovalent and divalent verbs.

(12) [ki:tan] [wa:pa] dan ton sleep dog pathway LOCATIVE ' The dog slept on the pathway. '

(13)

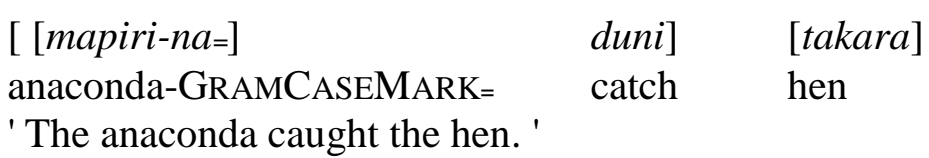


Case morphology occurs only on noun phrases standing for 1. the agent of II verbs; 2. the intrinsic linkee of II nouns (i.e. the entity obligatorily coupled to "inalienably possessed" nouns), and 3. as a semantic ("inherent") case-marker on allative adjuncts. The grammatical-case marker $n a$ (GRAMCASEMARK in glosses) is phonologically bound to the verb, hence the notational convention $-\mathbf{n a}=$, which shows its split status in terms of hosts, [-] for grammatical on the left $v s$. [=] for phonological on the right. Adjuncts are obliquely marqued (one single case, or inflectable postpositions), as dan in (12). Adpositional verbs have not been observed. Basic constituency and word order feature $\left[{ }^{\mathrm{I}}\right.$ verb $]+[$ unique argument $]$ and $[$ [agent argument $]+{ }^{\mathrm{II}}$ verb $]+[$ patient argument]. Not only case and word order align the unique argument noun phrase with the transitive patient noun phrase, but also 1) constituency (partially responsible for linear order): the unique and patient noun phrases are external to the verb phrase and post-verbal, whereas the agent noun phrase is internal and pre-verbal, see constituency brackets in (12), (13) and (14); 2) pronominalization: the agent referent requires a bound form prefixed to the verb, whereas the unique argument and the patient argument exhibit a free pronoun, as in:

(14) $[$ a-duni] [anyan]

3SINGULAR-catch 3

' He caught it. '

Pronominal forms, bound and free, distinguish three persons and two numbers.

$\begin{array}{llll}\text { singular } & \text { plural } & \text { singular } & \text { plural } \\ \text { adu } & \text { adik } & y(o)- & \text { tyo- } \\ \text { idi: } k & \text { idi:ki } & n o- & n a- \\ \text { anyan } & \text { anyan-hi=nuk } & (h) a- & \text { ma- }\end{array}$

Other clues to an ergative-type alignment, more on the behaviour cline, are extraction operations such as left dislocation, contrastive focalization, interrogation, relativization, all accessible to the patient and unique arguments, but not to the agent argument (for more detailed accounts of Katukina-Kanamari ergativity $c f$. Queixalós 2010, 2017). See focalization in (16)-(17): 
(16) takara tu kana mapiri-na= duni

hen NEGATION FOCUS anaconda-GRAMCASEMARK= catch

' It was not the hen that the anaconda caught. '

(17) wa:pa kana ki:tan dan ton

dog FOCUS sleep pathway LOCATIVE

' It was the dog that slept on the pathway. '

Except for co-reference control, which does not thoroughly pattern with respect to the ergative / accusative divide, Katukina is a fairly homogenous ergative language in its coding and behaviour alignments.

(18) semantic roles argument coding grammatical relations

$$
\begin{aligned}
& \text { agent } \\
& \text { ergative } \\
& \text { object }
\end{aligned}
$$

patient absolutive subject

\section{verb argument}

Nonetheless, an accusatively aligned clause-type exists, requiring a generic patient participant.

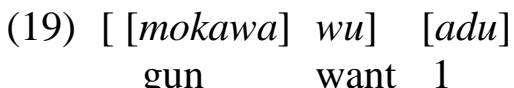

' I want guns. '

Voice is an agent's promotion device primarily required to give its argument expression access to otherwise beyond reach syntactic operations. Interestingly enough, the means to trigger this antipassive voice is, in terms of verb morphology, quite similar to that used in the accusative-language Sikuani for passive: blocking the access of any referent to the agent verb position by saturating the latter with a referentially empty form, in this occasion the prefix $w a$-. The agent rises to subject absolutive argument, out of the verb phrase, and the patient is demoted either to lack of realization or to adjunct position, with or without oblique marking.

(20) wa- $O$

\section{opatyin}

ANTIPASSIVE-drink child

' The child drank. '

As an external noun phrase, the agent argument has now acces to focalization and other behavioural properties. 
(21) opatyin $t u \quad k a n a$ wa- $o$

child NEGATION FOCUS ANTIPASSIVE-drink

' It is not the child that drank. '

\section{3 'Give' verbs}

I will now describe sequentially the morphosyntax of verbs denoting 'give' in both languages.

\subsection{Sikuani}

'Give' surfaces as a ${ }^{\text {III }}$ verb. The basic word order is [agent argument + patient argument $+{ }^{\mathrm{III}}$ verb + recipient argument]:

\section{(22) Nusalia tsema rahuta Yokopi \\ Nusalia tobacco give Yokopi \\ 'Nusalia gave tobacco to Yokopi. '}

Alignement properties will be stated by comparing each of the arguments

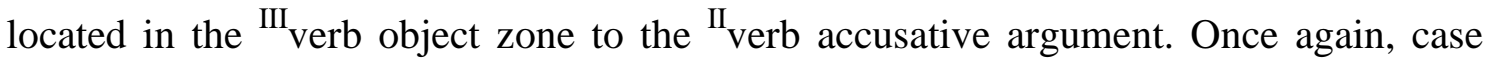
marking does not help. The two other available properties, word-order and verb morphology, feature a split: as (22) shows, preverbal position aligns the patient argument with the accusative noun phrase of ${ }^{\mathrm{II}}$ verbs, (2). We know, however, that word order is flexible to a certain extent. Thus the patient argument can occur post-verbally as does its II verb counterpart, mainly when all three arguments do not surface as noun phrases, a rather common situation in discourse (with possible alignment consequences due to topicality), (23). Verbal morphology is the most reliable clue to alignment. By it the recipent argument aligns with the ${ }^{{ }^{I I}}$ verb accusative, compare (23) with (6) renumbered (24): the same second person prefix $k a$ - indexes the ${ }^{\text {III }}$ verb recipientargument and the ${ }^{\mathrm{II}}$ verb accusative. This pathetive $e^{4}$ alignment holds in syntax: only the accusative argument is accessible to passivization, (25).

\footnotetext{
${ }^{4}$ The case not aligning with any of those found in ${ }^{\mathrm{I} / \mathrm{II}}$ clauses. Since pacientive is often used to indicate a semantic role, I recycle Mel'cuk (2006 154)'s term pathetive (originally the case of the ${ }^{\mathrm{II}}$ verb patient argument in a language like Dyirbal), so as to name the alignment that Haspelmath (2005) calls secundative following Dryer (1986)'s terminology for objects, that I eschew for reasons to be explained hereafter.
} 
(23) nihamonae $_{1} \mathbf{k a}_{2}-$ rahuta- $_{1}$

YourFamily 2 ACCUSATIVE-give-3NOMINATIVE fish

'Your family gave you $_{2}$ the fish ${ }_{3}$.'

(24) penahorobinü $\mathbf{u}_{1} \mathbf{k a}_{2}$-itoya- $\emptyset_{1}$

shaman 2ACCUSATIVE-hate-3NOMINATIVE

' The shaman 1 hates you 2 . '

(25) peruhuwayo $\emptyset_{1}$-rahuta-tsi ${ }_{0}$

OldWoman 3ACCUSATIVE-give-4NOMINATIVE

' The old woman 1 was given it. '

Touching the promotion of III verb accusative arguments to subject status, directly relevant data are missing. As a hint to the plausibility of such a configuration, I first attempt at building a reconstructed example (26) based on (25), then provide a fairly-parallel spontaneous example with an applicative ${ }^{\text {III }}$ verb, (27). (Note, however, that in certain aspects - mainly related to animacy hierarchies — a cross-linguistic parallelism between applicative objects and non-derived objects cannot be totally taken for granted; Peterson 2007 55; Rose 2012.)
? peruhuwayo 1
baitsi
$\emptyset_{1}$-rahuta-tsi $i_{0}$
OldWoman OVERTHEMATIZER 3ACCUSATIVE-give-4NOMINATIVE
' The old woman, she was given it. '
beweria hiwi ${ }_{1}$ raha baitsi $\emptyset_{1}$-to-ruba-tsi $i_{0} \ldots$
OverThere people ASSERTIVE OVERTHEMATIZER 3ACCUSATIVE-APPLICATIVE- hang-4NOMINATIVE

' Everywhere the people they $_{1}$ were bestowed on [the civilizational precepts $\left.\mathrm{w}_{2}\right] .$. '

...pe $e_{1}-\emptyset_{2}$-tae-nexa

3POSSESSIVE-3ACCUSATIVE-see/know-PURPOSE

'...so as they ${ }_{1}$ be aware of them ${ }_{2}$. '

It is worth noting, here, that the covert realization of the patient participant of 'bestow', 'the precepts', is echoed by its — no-less covert — co-indexing $\emptyset_{1^{-}}$as a mandatory position in the morphology of the subordinate 'know', second line.

We now turn to the "antidative" alternation. When the patient participant outranks the recipient in a saliency scale such as person (less frequently: mere animacy), a renegotiation of the arguments' grammatical hierarchy takes place in the object zone so as to raise the patient to the accusative position. The recipient then is relegated to 
adjunct status and marked by a complex locative form: a suffix -hawa whose function is spatializing humans, plus the postposition for unmarked-orientation beria.

$\begin{array}{llll}\text { axa }_{1} & \text { ne }_{2} \text {-rahuta- } \emptyset_{1} & \text { Kawirimonae }_{3} \text {-hawa } & \text { beria } \\ \text { MyFather } & \text { 1ACCUSATIVE-give- } & \text { KawiriPeople- } & \text { CENTRIFUGALALLATIVE } \\ \text { 3NOMINATIVE } & \text { EXTERNALZONE }\end{array}$

In synthesis, as far as 'give' constructions are concerned, Sikuani displays the trivalent type so-called primary / secundary objects (Dryer 1986). To the extent that we keep as distinct the three following levels of linguistic structure: ${ }^{5} 1$. semantics (participants in a manner-of-existing), 2. coding (arguments as the linguistic form of participants), and 3. grammatical relations (syntactically herarchized arguments), in trivalent clauses of the 'give' type we will have either (29a) (French-like) or (29b) (Sikuani-like) as the most common alignments in basic clauses:

$$
\text { II verb } \quad \text { III }
$$

a

semantic roles argument coding grammatical relations

b

semantic roles argument coding grammatical relations patient accusative direct object

patient accusative direct object

\begin{tabular}{l|l}
\hline patient & recipient \\
$\begin{array}{l}\text { accusative } \\
\text { direct object }\end{array}$ & $\begin{array}{l}\text { dative } \\
\text { indirect object }\end{array}$ \\
\hline $\begin{array}{l}\text { recipient } \\
\text { accusative } \\
\text { direct object }\end{array}$ & $\begin{array}{l}\text { patient } \\
\text { indirect object }\end{array}$
\end{tabular}

Excursus. I sustain that we do not need two sets of objects, direct / indirect and primary / secundary, in order to account for both alignment-types of 'give' verbs (regarding causatives see Queixalós 2002). Such a distinction within the object zone has as its only basis the cross-over projection of semantic roles upon arguments as displayed in (29)'s cells. In doing so, on one side we collapse semantics and coding (as we flag distinct roles in spite of the evidence for one and the same formal treatment given by the language), and on the other side we collapse coding and grammatical relations (as we identify distinct "objects", e.g. direct / primary, where we have mere distinct codings).

\footnotetext{
${ }^{5}$ Logically a necessary condition for whoever strives to disentangle the intricacies in the interaction between function and form on the one hand, and, within the level of form, between coding and behaviour / control properties on the oher hand.
} 
On a third side, we overlook the parsimony principle by creating inessential new terminology. Obviously, a concern that comes to mind here is the need for the proposed case-name pathetive in (29b). The fact is, we do not seem to have a term for something like a II verb patient argument qualifying for neither accusative nor absolutive, see footnote 2 above. In Sikuani pathetive case occurs on the patient argument of primary and derived ${ }^{\mathrm{III}}$ verbs: no verbal indexing but a noun phrase left unmarked for case, (31). From a similar perspective, Blansitt 1984 puts forward dechticaetiative. As the passive examples have made patent, Sikuani does feature, as distinct from argument-coding and owing to its capacity to rise to passive subject, a grammatical relation object, hence the validity of the object-zone notion as applied to ${ }^{\mathrm{III}}$ clauses. A paradigmatic instance of the same theoretical stand regarding what is here called object zone can be found in Kozinsky \& Polinsky (1993)'s substantiation of Corean causatives as exhibiting double accusative but not double object. ${ }^{6}$ Thanks to carefully distinguishing between both levels of structure, Chamoreau (2008) can detect a further refinement in the object zone of the Purepecha language: a double accusative on the coding side and, at the syntactic level, a double object regarding extraction / reference-control but a patient-prominent alignment regarding valency-changing alternations. End of excursus

Finally, Sikuani applicatives on primary ${ }^{\text {II }}$ verbs yield derived ${ }^{\text {III }}$ verbs in which the promoted participant - generally high in some animacy scale — surfaces as direct object (see also (27)):

(30) awiri $\boldsymbol{\emptyset}_{1}$-beyaxuaba-me 2

dog 3ACCUSATIVE-kill-3NOMINATIVE

' $\mathrm{You}_{2}$ killed the $\operatorname{dog}_{1}$.'

(31) awiri $_{1}$ ne-to-beyaxuaba-me 2

dog 1ACCUSATIVE-APPLICATIVE-kill-3NOMINATIVE

' $\mathrm{You}_{2}$ killed $\mathrm{my}_{3} \operatorname{dog}_{1}$.'

\subsection{Katukina-Kanamari}

In this language no III verbs exist. A II verb man is secondarily used for 'say'. Its transferred participant, a direct-discourse stretch, accesses none of the formal properties attached to argumenthood. Thus, in (32) the sequence $\{\ldots\}$ embodies the quoted

\footnotetext{
${ }^{6}$ Nonwithstanding the, in my sense, non-conclusive refutation by Jaehoon (2007).
} 
fragment whereas the bracketed sequence displays the verb and its two arguments realizing the source 'woman' and the destination, 'me'. The 'say' acceptation retains the original 'do/get' two-place valency we can see in (33), while allotting the external argument position in (32) to the destination participant, 'me'. Nuhuk, 'give, sell', behaves

like any ${ }^{\text {II }}$ verb, with the patient participant surfacing as an absolutive external argument ranked as subject, and the agent surfacing as an ergative internal argument ranked as object, see (18). The recipient appears as an adjunct, marked obliquely for allative, a case suffix -na in one dialect, a postposition ton in the other.
$\{$ daan adu wa
bo! $\}$
[ [ ityaro $\left._{1}-n a=\right]$
man $] \quad\left[a d u_{2}\right]$

go 1 FUTURE ASSERTIVE woman-GRAMCASEMARK= do/say 1

' The woman 1 said to $\mathrm{me}_{2}$ : "I'll go away!" '

$\begin{array}{llllll}\text { atyowa } & \text { ityonin } & \text { naki } & \text { [atyowa } & \text { bara }] & \text { [ [tyo-]man] } \\ \text { our } & \text { jungle } & \text { LOCATIVE } & \text { our } & \text { WildMeat } & \text { 1PLURAL-do/get }\end{array}$

' In our jungle we get our wild meat. '
$\left[\left[\right.\right.$ Ayobi $\left._{1}-n a_{=}\right]$

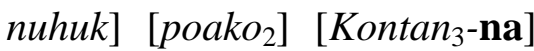
Ayobi-GRAMCASEMARK= give row Kontan-ALLATIVE
'Ayobi ${ }_{1}$ gave the row 2 to Kontan 3 . '

BIA KATUKINA

(35)
[ [OKi $\left.i_{1}-n a=\right]$
nuhuk] [poako 2 [ $\mathrm{YaO}_{3}-n a=$
ton]
Oki-GRAMCASEMARK= give
paddle
Yao-GRAMCASEMARK = ALLATIVE
' $\mathrm{Oki}_{1}$ gave the row 2 to $\mathrm{YaO}_{3}$.'

KANAMARI

(Postpositions govern differential case-marking: $-n a=$ only occurs with nouns denoting human or personified participants. The same case-procliticization that we met above on verbs takes place here.) No structure-changing shift having the recipient expression raised from adjunct to external argument - typically that denoting the patient - exists. To every proposed example featuring a human noun in that position speakers simply respond with the noun's referent being transferred to some unnamed recipient (something of a "zero-marked applicative"). Since the object zone is missing in a ${ }^{\text {III }}$ verb-less language, the absence of any (anti)dative syntactic derivation is expected.

Also expected is the fact that applicatives on II verbs have no effect on valency. They simply reallocate the argument position to the promoted participant while expelling the original patient to the adjunct periphery. 
(36) $y o_{1}$-wando:ki $\operatorname{don}_{2} w a$

1SINGULAR-cook fish FUTURE

' $\mathrm{I}_{1}$ am going to cook the fish 2 .'

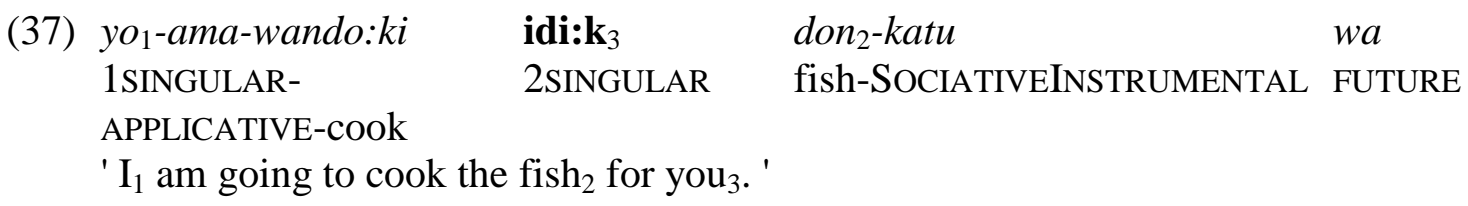

\section{Discussion}

Thus far, I have shown that Sikuani and Katukina-Kanamari contrast in a number of grammatical aspects relevant to the issues at stake: verb morphology, argument alignment, constituency and word-order, case-marking, grammatical relations, and the existence / non-existence of trivalent verbs. Several authors (e.g. Manning 1996 42) have pointed out that 'give'-equivalent verbs do not occur as ${ }^{\text {III }}$ verbs in syntactically ergative languages. Katukina-Kanamari confirms this empirical observation, as do Dyirbal (Dixon 1972), Central Alaskan Yup'ik (Mithun 2000) and Movima (Haude, nd.). Other ergative languages, those whose syntax is accusatively oriented, seem perfectly compatible with such verbs, for instance Basque, Matsés (Fleck 2003864 ff.), and Inuit (Bittner \& Hale 1996). The point of note for our purposes is that, conversely, the lack of ${ }^{\mathrm{III}}$ verbs is no diagnostic of ergative syntax. Thus, !Xun, for instance, is not ergative while being ${ }^{\mathrm{III}}$ verb-less. Now, regarding Central Arctic Eskimo and Dyirbal syntactically ergative —, Marantz (1984 209) discards any interdependence between ergative-absolutive case marking and the lack of ${ }^{\text {III }}$ verbs. Putting these languages on an equal footing with Matses on the mere commonality of argument coding seems a rather surprising appraisal on the part of an author that places maximal emphasis on syntax as the hallmark of ergatively-oriented grammatical relations.

My notion of objet zone, together with the cognitive prominence of the agent participant, is crucial for giving a judicious content to such assessment. If, as I contend, on purely syntactic grounds the absolutive argument of ${ }^{\text {II }}$ verbs in a language such as Katukina-Kanamari is entitled to the status of subject and the ergative argument to that of object (see, in the same vein, Marantz $1984196 \mathrm{ff}$; and, in a different terminology, Van Valin 2007), a would-be ${ }^{\text {III }}$ verb in such a language should abide by two alternative options: either it features 
1. an argument structure whereby two participants, agent plus patient or agent plus recipient, are allocated to a non-subject zone, or

2. a grammatical-relation pattern allowing for the carbon-copy counterpart of the above posited object zone, to wit: a subject zone hosting patient plus recipient or even patient plus agent.

As for option 1., the cross-linguistic asymmetries between the agent on one side and the rest of major semantic roles on the other are too well documented and principled (Keenan \& Comrie 1977's accessibility hierarchies; Givón 2001 108's mappings; Dowty 1991 's selection) to accommodate such amalgamations of roles. And, last but not least, the conceptual oddity of something like a subject zone makes the possibility of option 2 . even more questionable.

In sum, behind the as yet undocumented existence of ${ }^{\mathrm{III}}$ verbs in syntactically ergative languages lies a simple rationale: the combined levels of structure semantic roles / grammatical relations simply preclude the existence of any kind of formal cluster — "zone" — that would host two arguments jointly contrasting with a third one.

\section{REFERÊNCIAS}

ANDREWS, A. D. The major functions of the noun phrase. SHOPEN, T. (ed.) Typology and Syntactic Description, London / New York: Cambridge University Press, p. 132-223, 2007

BITTNER, M.; HALE, K. Ergativity: Toward a Theory of a Heterogeneous Class. Linguistic Inquiry, 27.4, p. 531-604, 1996

BLANSITT, E.L. Jr. Dechticaetiative and dative. PLANK, F. (ed.) Objects, London: Academic Press, p. 127-150, 1984

BUGAEVA, A. Ditransitive constructions in Ainu. Sprachtypologie und Universalienforschung, 64.3, p. 237-255, 2011 
CHAMOREAU, C. Ditransitive constructions in Purepecha: a hybrid type.

QUEIXALOS, F. (ed.) Relations grammaticales dans les langues d'Amazonie,

Amerindia 31, p. 157-180, 2008

COMRIE, B. Language Universals and Linguistic Typology, Oxford: Basil

Blackwell, 1981

DIXON, R. M. W. The Dyirbal language of North Queensland, London / New York: Cambridge University Press, 1972

DOWTY, D. Thematic Proto-Roles and Argument Selection. Language, 67.3, p. 547619, 1991

DRYER, M. S. Primary Objects, Secondary Objects, and Antidative. Language. 62.4, p. $808-845,1986$

EVANS, N. D. A Grammar of Kayardild, Berlin / New York: Mouton de Gruyter, 1995

FLECK, D. W. A Grammar of Matses, Ph.D. Dissertation, Houston: Rice University, 2003

GIVÓN, T. Direct object and dative shifting: semantic and pragmatic case. PLANK, F. (ed.) Objects: Towards a theoy of grammatical relations, London: Academic Press, p. 151-182, 1984

GIVÓN, T. Syntax: An introduction I, Amsterdam / Philadelphia: John Benjamins, 2001

HASPELMATH, M. Argument marking in ditransitive alignment types. Linguistic Discovery. 3.1, p. 1-21, 2005

HAUDE, M. The expression of three-participant events in Movima. Disponível em: https://www.thefreelibrary.com/The+expression+of+three-

participant+events+in+Movima.-a0331807007, consulted April 182021

Jaehoon, Y. "Coding Conflict or Semantic Contrast? The Grammatical Encoding of the Causee' Eoneohag (Journal of the Linguistic Society of Korea), 47.4, p. 33-59, 2007

JELINEK, E. Grammatical Relations and Coindexing in Inverse Systems. DZIWIREK, K., FARRELL, P. \& MEJIAS-BIKANDI, E. (eds) Grammatical Relations: a CrossTheoretical Perspective, Stanford: The Stanford Linguistics Association, p. 227-246, 1990 
KEENAN, E.; COMRIE, B. Noun-Phrase Accessibility and Universal Grammar. Linguistic Inquiry, 8.1, p. 63-99, 1977

KISSEBERTH, C. W.; ABASHEIKH, M. I. The object relationship in chi-mwi:ni, a bantu language. COLE, P. ; SADOCK, J. M. (eds) Grammatical relations, New York: Academic Press, p. 179-218, 1977

KÖNIG, C.; HEINE, B. Are there ditransitive verbs in !Xun?. MALCHUKOV, A., HASPELMATH, M.; COMRIE, B. (eds) Studies in Ditransitive Constructions. A Comparative Handbook, Berlin / New York: Mouton de Gruyter, p. 74-114, 2011

KOZINSKY, I.; POLINSKY, M. Causee and patient in the causative of transitive: Coding conflict or doubling of grammatical relations?. COMRIE, B.; POLINSKY, M. (eds) Causatives and Transitivity, Amsterdam / Philadelphia: John Benjamins, 1993

MALCHUKOV, A.; HASPELMATH, M.; COMRIE, B. Ditransitive constructions: A typological overview. MALCHUKOV, A., HASPELMATH, M.; COMRIE, B. (eds) Studies in Ditransitive Constructions. A Comparative Handbook, Berlin / New York: Mouton de Gruyter, p. 1-60, 2011

MEIRA, S. A Grammar of Tiriyó, PhD. Dissertation, Houston: Rice University, 1999 Melcuk, I. Aspects of thc theorv of morphology, edited by David Beck, Berlin / New York: Mouton de Gruyter, 2006

MITHUN, M. Valency-changing derivation in Central Alaskan Yup'ik. Dixon, R.M.W. \& Aikhenvald, S. Changing valency. Case studies in transitivity, Cambridge: Cambridge U. Press, p. 84-113, 2000

Payne, D.; PAYNE, T. YAGUA DERBYSHIRE, D.; PULlUM, G. (eds), Handbook of Amazonian Languages 2, Berlin / New York: Mouton de Gruyter, p. 249-473, 1990 PETERSON, D. A. Applicative Constructions, Oxford: Oxford University Press, 2007

QUEIXALÓS, F. The notion of transfer in Sikuani causatives. SHIBATANI, M. (ed.) The grammar of causation and interpersonal manipulation, Amsterdam / Philadelphia: John Benjamins, p. 319-339, 2002

QUEIXALÓS, F. Grammatical Relations in Katukina-Kanamari, GILDEA, S. \& QUEIXALÓS, F. (eds) Ergativity in Amazonia, Amsterdam / Philadelphia: John Benjamins, p. 235-284, 2010 
QUEIXALÓS, F. What being a Syntactically Ergative Language means for KatukinaKanamari. COON, J., MASSAM, D. \& TRAVIS DEMENA, L. (eds) The Oxford Handbook of Ergativity, Oxford: Oxford University Press, p. 1035-1064, 2017

ROSE, F. Competition for the Object Status: The Effects of Referential Factors in Mojeño Trinitario Derived and Non-Derived Ditransitive Verbs. Linguistic Discovery, 10.3 , p. 17-36, 2012

VAN VALIN, R. The Role and Reference Grammar analysis of three-place predicates. Suvremena Lingvistika 33.1.63, p. 31-64, 2007 